\title{
EFFECT OF CHLORAMPHENICOL ON THE ISOLATION OF S. TYPHI FROM THE BLOOD STREAM
}

\author{
BY \\ KENNETH C. WATSON \\ From the Natal Provincial Administration, Grey's Hospital, Pietermaritzburg, South Africa
}

(RECEIVED FOR PUBLICATION JUNE 9, 1954)

The usually excellent clinical response to chloramphenicol in typhoid fever has been accompanied in practically all the recorded series by a rapid disappearance of organisms from the blood stream. Cook and Marmion (1949) state: "The action of 'chloromycetin' appears to be to arrest the disease at whatever stage it has reached and to sterilize the blood at the same time." Marmion (1952) in a series of 330 cases in Service personnel found that "blood culture almost invariably became sterile within a few hours of starting chloramphenicol therapy." Woodward, Smadel, Ley, Green, and Mankikar (1948) found two cases where it was possible to isolate $S$. typhi from the blood stream after the patients had been on chloramphenicol for 24 hours, but considered this to be unusual.

Our experience has been at variance with that of others, and, following the isolation of 'S. typhi from a case on treatment with the antibiotic, using the clot culture method we have already described (Thomas, Watson, and Hewstone, 1954), we were able to isolate the organism on 16 occasions from 15 cases in a series of 93 cases. In each of these the patients were receiving what were considered to be theoretically adequate doses of chloramphenicol.

\section{Method of Clot Culture}

Five millilitres of blood was removed from the antecubital fossa, or from the femoral vein in the case of infants, and allowed to clot. After removal of the separated serum the clot was added to $15 \mathrm{ml}$. of bile salt broth containing 100 units $/ \mathrm{ml}$. of streptokinase, which produces rapid clot lysis. Subcultures were plated daily on to Wilson and Blair's medium. Results are detailed in Table I.

In each of the above cases the chloramphenicol content of the separated serum was estimated using a broth dilution technique against a standard solution of pure chloramphenicol, with Shigella sonnei as the test organism. In all 16 instances the serum level lay between 20 and $45 \mu \mathrm{g}$. $/ \mathrm{ml}$. Each of the
16 strains isolated was found to be sensitive to concentrations of chloramphenicol of from 0.5 to $3 \mu \mathrm{g} . / \mathrm{ml}$.

TABLE I

ISOLATION OF $S$. TYPHI FROM BLOOD CLOT

\begin{tabular}{c|c|c|c|c|c}
\hline No. & $\begin{array}{c}\text { Case } \\
\text { No. }\end{array}$ & $\begin{array}{c}\text { No. of Days' } \\
\text { Treatment } \\
\text { Before } \\
\text { Specimen } \\
\text { Taken }\end{array}$ & $\begin{array}{c}\text { Last Dose } \\
\text { Before } \\
\text { Specimen } \\
\text { Taken } \\
\text { (mg.) }\end{array}$ & $\begin{array}{c}\text { Total } \\
\text { Dosage } \\
(\mathrm{g} .)\end{array}$ & $\begin{array}{c}\text { No. of } \\
\text { Das s' } \\
\text { Incuba- } \\
\text { tion } \\
\text { Required }\end{array}$ \\
\hline 1 & 1955 & 10 & 250 & 10 & 2 \\
2 & 2490 & 2 & 500 & 4 & 2 \\
3 & 3179 & 1 & 500 & 2 & 2 \\
4 & 3714 & 2 & 250 & 2 & 3 \\
5 & 3712 & 1 & 500 & 2 & 1 \\
6 & 4192 & 1 & 500 & 1 & 2 \\
7 & 5536 & 8 & 250 & 8 & 2 \\
8 & 6387 & 2 & 500 & 2 & 3 \\
9 & 6078 & 2 & 500 & 3 & 3 \\
10 & 6078 & 11 & 500 & 22 & 1 \\
11 & 6760 & 2 & 500 & 2 & 1 \\
12 & 6757 & 2 & 250 & $1 \cdot 5$ & 1 \\
13 & 6756 & 2 & 250 & 3 & 2 \\
14 & 65 & 2 & 250 & 3 & 2 \\
15 & 6759 & 3 & 250 & 4 & 3 \\
16 & 373 & 1 & 250 & $1 \cdot 5$ & 1 \\
\hline
\end{tabular}

Routine blood cultures were performed at the same time as the clot cultures by adding $8-10 \mathrm{ml}$. of blood to $35 \mathrm{ml}$. of bile broth in screw-capped $4-\mathrm{oz}$. bottles. Again subcultures were plated daily on to Wilson and Blair's medium. Only one positive isolation was obtained in this way. The reason for this is presumably that the effective bacteriostatic concentration of chloramphenicol was still sufficient in the bloodmedium mixture to prevent growth of viable organisms in addition to the bactericidal action of serum factors not sufficiently diluted by the volume of medium used (Watson, 1954). In the case of the clot cultures, however, removal of the serum before culture has eliminated both these factors and the small quantity of each left in the volume of serum retained in the clot meshwork was not sufficient to prevent growth of viable organisms when diluted out in $15 \mathrm{ml}$. of medium.

\section{Reasons for Positive Isolations from Clots}

The action of chloramphenicol is primarily a bacteriostatic one (Smadel, 1950), though Bliss and 
Todd (1949) have shown a slow bactericidal action. If the observations of Smadel are correct it seemed possible that the explanation of the positive clot cultures might be the presence of circulating viable organisms which could be demonstrated by removal or suitable dilution of the antibiotic. Another explanation presented itself, however, namely, that viable organisms might be phagocytosed in vivo and be protected from the action of chloramphenicol by virtue of their intracellular position. Support for this observation is to be found in the work of Rous and Jones (1916), who demonstrated protection of intracellular forms of $S$. typhi from the action of specific antiserum and potassium cyanide. Adams (1939) has demonstrated intracellular forms of $S$. typhi in plasma cells in intestinal and mesenteric lesions. Magoffin and Spink (1951) have shown protection of intracellular forms of $\mathrm{Br}$. abortus, phagocytosed by cells of the buffy coat, from the bactericidal action of streptomycin.

\section{Demonstration of Protection of Intracellular Forms}

This problem was investigated using streptomycin in a manner somewhat similar to that described by Magoffin and Spink (1951). Streptomycin was chosen, since the authors have shown that with chloramphenicol and the other broad spectrum antibiotics death of extracellular forms occurs too slowly to allow protection of intracellular forms to be demonstrated before death and disintegration of the harbouring leucocytes.

Method.-Twenty millilitres of blood from a donor was added to $2 \mathrm{ml}$. of $3.8 \%$ sterile sodium citrate. After centrifuging at 3,000 revs. for 20 minutes the buffy coat was transferred to a sterile Wintrobe tube and spun again. The buffy coat was then removed and divided into two equal parts. One-half $\mathrm{ml}$. of a 1 in 1,000 saline dilution of an overnight broth culture of a freshly isolated strain of $S$. typhi was added to one part in a sterile 3 in. by $\frac{1}{2}$ in. tube, which was then incubated in a water bath at $37^{\circ} \mathrm{C}$. for four hours. Gram-stained films then showed the presence of intracellular forms. Five millilitres of streptomycin solution containing $100 \mu \mathrm{g} . / \mathrm{ml}$. was then added. A control tube containing the other part of the buffy coat, S. typhi suspension, and streptomycin was set up but without preliminary incubation of the buffy coat and bacterial suspension.

Both tubes were incubated at $37^{\circ} \mathrm{C}$. in a water bath. At varying periods of incubation $0.5 \mathrm{ml}$. amounts were removed and serial tenfold dilutions prepared in saline. Plate count estimations of surviving organisms were then made. Results are detailed in Table II.
TABLE II

ACTION OF STREPTOMYCIN ON INTRACELLULAR AND EXTRACELLULAR FORMS OF $S$. TYPHI

\begin{tabular}{|c|c|c|c|}
\hline \multirow{2}{*}{$\begin{array}{c}\text { Time of } \\
\text { Incubation } \\
\text { (Hours) }\end{array}$} & \multirow{2}{*}{ Dilution } & \multicolumn{2}{|c|}{ Colony Counts per $1 \mathrm{ml}$. Vol. } \\
\hline & & Test Sample & Control Sample \\
\hline $\begin{array}{l}12 \\
24\end{array}$ & $\begin{array}{l}1 / 10 \\
1 / 100 \\
1 / 1,000 \\
1 / 10 \\
1 / 100 \\
1 / 1,000 \\
1 / 10 \\
1 / 100 \\
1 / 1,000 \\
1 / 10 \\
1 / 100 \\
1: 1,000\end{array}$ & $\begin{array}{r}310 \\
63 \\
14 \\
230 \\
42 \\
8 \\
240 \\
31 \\
6 \\
190 \\
30 \\
4\end{array}$ & $\begin{array}{c}30 \\
4 \\
\text { Nil } \\
\ddot{"} \\
\ddot{"} \\
\ddot{~ " ~} \\
\ddot{~} \\
\ddot{~}\end{array}$ \\
\hline
\end{tabular}

\section{Discussion}

The results in Table II demonstrate clearly that where intracellular forms were present growth was significantly better than in the control series where $T_{\mathbb{D}}$ no phagocytosis took place. These findings, in $\frac{O}{2}$ conjunction with the observations of Adams (1939), ฏ appear to supply a rational explanation of the $₹$ results in Table $I$. It is probable that where phago- $\vec{\oplus}$ cytosis occurs in vivo a proportion of the phago- of cytosed organisms remain viable for a certain o length of time and are protected from circulating antibiotic. In this connexion it is interesting to note that no demonstration of intracellular penetration by chloramphenicol is as yet forthcoming. $\frac{}{D}$ The work of Smith, Worrel, and Swanson (1949) suggests that a barrier exists at the cell wall. Glazko, Wolf, and Dill (1949), concerning the distribution of chloramphenicol in red cells, state : "The binding is probably due to adsorption rather than slow diffusion through the cell membrane."용 This has been our experience also.

Rous and Jones (1916) showed that intracellular protection was dependent on the cells being alive. $ᄋ$ When death occurred changes in the permeability of the cell walls led to the contained organisms $ᄋ$ being exposed to the action of bactericidal factors. $D$

Though the isolation of $S$. typhi from the blood stream of cases on therapeutically adequate doses of chloramphenicol has not been reported to any $ᄋ$ extent by others, $S$. typhi has been isolated after $N$ death from various tissues (Reilly, Compagnon, 出 Tournier, Bastin, and du Buit, 1950 ; Marmion, 0 1952). If the observations of Adams (1939) are correct, it is probable that intracellular forms of $\frac{D}{\Phi}$ $S$. typhi were present in these tissues. It may be $\stackrel{?}{?}$ that such foci of organisms are responsible for 0 maintaining an intermittent bacteraemia and that, $\overline{0}$ in view of the primarily bacteriostatic action of $\stackrel{\mathbb{Q}}{\Omega}$ chloramphenicol, positive isolations will be ob- $\frac{\widetilde{\Phi}}{\mathbb{D}}$ tained during this time provided there is adequate $\frac{O}{0}$ dilution or removal of the antibiotic. 


\section{CHLORAMPHENICOL AND}

Only one positive blood culture was obtained as against 16 positive clot cultures. This suggests that the volume of culture medium in the former, $35 \mathrm{ml}$., was too small, since with adequate dilution of chloramphenicol and serum factors an equal number of positive blood cultures would be expected. We have already shown that the results of clot culture using streptokinase bile broth are considerably superior to the routine blood culture results using this volume of medium, and that this is due to a sufficient concentration of bactericidal serum factors in the latter (Watson, 1954).

If the intermittent release of intracellular forms in tissue into the blood stream is the true explanation of the results in Table $I$, it is necessary to postulate some mechanism of release from the cells. This may follow death of the cells, but Wilson (1953) has recently shown by phase-contrast microscopy ingestion followed by egestion of viable forms of streptococci. It may be that a similar mechanism operates in this instance. The results in Table II are of course not directly applicable to the problem of the effect of chloramphenicol in vivo, but they do provide a possible explanation for the positive cultures reported in Table $I$.

\section{Summary}

Isolation of $S$. typhi from blood clot in 16 instances from 15 cases receiving theoretically adequate doses of chloramphenicol is presented.
Intracellular protection of phagocytosed forms of $S$. typhi from the action of antibiotics (streptomycin) is discussed.

A possible explanation of the positive clot cultures is given.

I am indebted to Dr. J. C. Thomas, Provincial Pathologist, Natal Provincial Administration, for his interest and encouragement. I wish to thank Messrs. Parke, Davis \& Co. for a supply of pure crystalline chloramphenicol.

\section{REFERENCES}

Adams, J. W. (1939). Amer. J. Path., 15, 561.

Bliss, E. A., and Todd, H. P. (1949). J. Bact., 58, 61.

Cook, A. T., and Marmion, D. E. (1949). Lancet, 2, 975.

Glazko, A. J., Wolf, L. M., and Dill W. A. (1949). Proc. Soc. exp. Biol., N.Y., 72, 602.

Magoffin, R. L., and Spink, W. W. (1951). J. Lab. clin. Med., 37, 924. Marmion, D. E. (1952). Trans. roy. Soc. trop. Med. Hyg., 46, 619.

Reilly, J., Compagnon, A., Tournier, P., Bastin, R., and Buit, H. du (1950). Ann. Méd., 51, 597.

Rous, P., and Jones, F. S. (1916). J. exp. Med., 23, 601.

Smadel, J. E. (1950). Trans. roy. Soc. trop. Med. Hyg., 43, 555.

Smith, G. N., Worrel, C. S., and Swanson, A. L. (1949). J. Bact., 58, 803.

Thomas, J. C., Watson, K. C., and Hewstone, A. S. (1954). Journal of Clinical Pathology, 7, 50.

Watson, K. C. (1954). Ibid., 7, 305.

Wilson, A. T. (1953). J. exp. Med., 98, 305.

Woodward, T. E., Smadel, J. E., Ley, H. L., Green, R., and Mankikar, D. S. (1948). Ann. intern. Med., 29, 131. 